\title{
PSYCHOLOGICAL AND LINGUISTIC FEATURES OF THE RUSSIAN LANGUAGE ACQUISITION BY INTERNATIONAL STUDENTS
}

\author{
I.A. Novikova \\ Chair of Social and Differential Psychology \\ Peoples' Friendship University of Russia \\ Miklukho-Maklaya str., 10/2, Moscow, Russia, 117198 \\ A.L. Novikov, M.A. Rybakov \\ Chair of General and Russian Linguistics \\ Peoples' Friendship University of Russia \\ Miklukho-Maklaya str., 10/2, Moscow, Russia, 117198
}

The paper presents the results of a full-scale interview with Russian language teachers that teach Russian as a foreign language at the preparatory departments at multinational universities. The research findings identified the basic psychological and linguistic features that are typical for the Russian language acquisition by the students from different regions of the world (Africa, Latin America, Southeast Asia, Arab countries).

Key words: Russian as a foreign language; Russian language teaching; Russian language acquisition; international students, intercultural communication and adaptation.

The knowledge of one or more foreign languages is essential for effective intercultural communication in today's super-diverse world [10]. The foreign (second) language acquisition is an important factor of the intercultural adaptation in the new socio-cultural environment [1;9]. Most international students name poor language skills among the main problems of their adaptation in a foreign country, as well as one of the difficulties of training at the university [8].

Russian universities have a lot of experience in teaching international students from different regions of the world. Most international students, who come to study in Russia, do not know the Russian language at all. Therefore, in the Russian universities, where international students study, there are special preparatory departments. International students learn the Russian language and the basics of their future major subject at preparatory departments for a year.

The Russian language curriculum for the international students includes the phonetic, grammatical and lexical aspects of language learning. The aim of this curriculum is the development of basic skills of speech activity, which are speaking, listening, reading and writing. An important part of this curriculum is to study not only the scientific style of speech (i.e. the terminology and concepts of professional language learning), but the rules of communicative behavior are based on linguistic and cultural standards $[2 ; 6]$.

The Russian language is a language difficult enough to learn. The Russian language has been classified as the third difficulty level of the four levels according to the study of The Defense Language Institute (DLI), Monterey, CA. 
It is evident that one of the difficulties for the beginners who learn the Russian language is related to the Russian alphabet. The Russian alphabet is derived from the Cyrillic alphabet and Russian cursive is also different from the Latin alphabet. In this connection at the beginning of the study the international students may have difficulties in reading and writing in Russian.

There are more serious problems in the Russian language study, for example:

- Russian phonetics has many complex sounds (sibilant sounds);

- Russian grammar has many cases, declensions, conjugations etc.;

- there are no strict rules for word order in Russian;

- there are too many exceptions to the rules in the Russian language, which is difficult even for native speakers [5].

It is known that the complexity of learning a foreign language is connected with the features of the native language, so students from different countries and regions may have different problems. In accordance with this fact, the aim of our study was to determine the basic linguistic and psychological difficulties in the Russian language acquisition, which are most typical for students from different regions of the world.

We used a full-scale questionnaire to interview the Russian language teachers who train international students at the preparatory departments of the multinational universities (Peoples' Friendship University of Russia and Moscow State Automobile and Road Technical University). 10 Russian language teachers (their work experience ranging from 25 to 50 years) took part in the interview. Each of them has had work experience with students from different regions of the world: African countries (Central, Eastern and Western Africa), Latin American countries (South America), the countries of Southeast Asia (China, Vietnam) and Arab countries (North Africa, the Near and Middle East).

We asked the experts to assess how easily and successfully the students from these regions learn the basic aspects of the Russian language and speech:

1) speaking (pronunciation (phonetics) and phrasing);

2) listening (listening and speech comprehension);

3) writing (cursive (graphic aspect) and the expression of thoughts);

4) reading (aloud and to themselves).

We asked how actively and fluently the students use the Russian language in communication in the classroom and outside the classroom. We also asked what are the typical psychological and educational features of the international students that help or hinder them in their language acquisition.

All of the experts point out that there is a wide variation in the ability to study the Russian language within each group of students from different regions. In recent years this variation has increased because more and more students lack motivation and diligence in their studies.

However, experts have concurrently named the linguistic features of the Russian language study, which are the most typical for each group of the international students (see table). 
Typical linguistic features of the Russian language study for different groups of the international students

\begin{tabular}{|c|c|c|c|c|}
\hline Group of student & Speaking & Listening & Writing & Reading \\
\hline Arab students & $\begin{array}{l}\text { Good pronunciation; } \\
\text { quickly learn the } \\
\text { vocabulary; } \\
\text { are not afraid of } \\
\text { grammar mistakes; } \\
\text { do not try to correct } \\
\text { errors, but it does } \\
\text { not stop them from } \\
\text { communication }\end{array}$ & $\begin{array}{l}\text { Good listening } \\
\text { comprehension } \\
\text { skills; have a good } \\
\text { linguistic intuition }\end{array}$ & $\begin{array}{l}\text { Bad cursive; } \\
\text { do not like to ex- } \\
\text { press their } \\
\text { thoughts in the } \\
\text { written form }\end{array}$ & $\begin{array}{l}\text { Have good reading } \\
\text { and comprehen- } \\
\text { sion skills }\end{array}$ \\
\hline African students & $\begin{array}{l}\text { Good pronunciation, } \\
\text { learn the vocabulary } \\
\text { slowly and in a stable } \\
\text { way; learn the gram- } \\
\text { mar with some diffi- } \\
\text { culty, but try and } \\
\text { repeat }\end{array}$ & $\begin{array}{l}\text { Good listening } \\
\text { comprehension }\end{array}$ & $\begin{array}{l}\text { Writing is slow and } \\
\text { careful }\end{array}$ & $\begin{array}{l}\text { Reading is slow } \\
\text { and careful }\end{array}$ \\
\hline $\begin{array}{l}\text { Latin American } \\
\text { students }\end{array}$ & $\begin{array}{l}\text { Problems in the pro- } \\
\text { nunciation of some } \\
\text { sounds; } \\
\text { quickly grasp the } \\
\text { grammar and voca- } \\
\text { bulary, but can for- } \\
\text { get without repeti- } \\
\text { tion }\end{array}$ & $\begin{array}{l}\text { Understanding of } \\
\text { the meaning of the } \\
\text { speech is quite } \\
\text { good }\end{array}$ & $\begin{array}{l}\text { Some difficulties } \\
\text { with writing letters, } \\
\text { which are different } \\
\text { in Russian and } \\
\text { Latin alphabets; } \\
\text { cursive is good; } \\
\text { trying to express } \\
\text { their thoughts in } \\
\text { written form }\end{array}$ & $\begin{array}{l}\text { Read aloud well } \\
\text { (with minor phonet- } \\
\text { ic problems); } \\
\text { good reading com- } \\
\text { prehension }\end{array}$ \\
\hline $\begin{array}{l}\text { Southeast Asia } \\
\text { students }\end{array}$ & $\begin{array}{l}\text { Big problems in pro- } \\
\text { nunciation (a differ- } \\
\text { ent phonetic basis); } \\
\text { difficulties in learn- } \\
\text { ing vocabulary and } \\
\text { grammar; } \\
\text { speaking with diffi- } \\
\text { culties and with } \\
\text { mistakes }\end{array}$ & $\begin{array}{l}\text { In the early stages } \\
\text { do not comprehend } \\
\text { speech by ear; } \\
\text { repetition and writ- } \\
\text { ing on the black- } \\
\text { board is necessary } \\
\text { for understanding }\end{array}$ & $\begin{array}{l}\text { Beautiful cursive; } \\
\text { they can rewrite } \\
\text { large pieces of } \\
\text { text without un- } \\
\text { derstanding }\end{array}$ & $\begin{array}{l}\text { They can read me- } \\
\text { chanically, with } \\
\text { phonetic errors, } \\
\text { without under- } \\
\text { standing, reading } \\
\text { is much easier for } \\
\text { them than talking }\end{array}$ \\
\hline
\end{tabular}

Arab students learn spoken Russian quickly and well. They have a good pronunciation and vocabulary. They do not try to correct grammar mistakes, so these errors may remain for a long time. Arab students use the Russian language in the classroom and outside the classroom actively, they usually have a lot of friends among the Russians. The teachers generally classify them as very capable of the Russian language learning. But these students may have the difficulties in communication with the teacher and other students because of psychological reasons. Their communication problems are related to their hot temper, impatience, pride, a very high self-esteem. At home they were accustomed to an authoritarian style of teaching. So, Russian teachers should be friendly to them but also strict, respectful, competent.

African students do not master the Russian language very fast, but they can overcome the difficulties with the help of diligence and repetition. African students, as a rule, besides their native language know the basics of a foreign language (English, French, Portuguese), and this fact helps them to learn the Russian language. They have the stable 
results in language learning, they usually show progress in the Russian language acquisition. They tend to communicate in Russian in the classroom and outside the classroom. The teachers describe them as friendly and smiling in communication, diligent in learning. Having a good understanding with the teacher can contribute to the success of their training.

Latin American students tend to have good abilities to learn the language, but they can be lazy, skip classes, they can show the lack of diligence. In the classroom, they grasp the material quickly, but superficially. A good educational background helps them to learn. They often use literature in their own language for a better understanding of the material in the profession. Later they usually accumulate the professional knowledge well. Sociability, activity, lack of barriers in communication with classmates and teachers help them to learn the Russian language. They like to take part in concerts and love singing both in their native language and in Russian. But our experts note that in recent years there have been frequently observed "atypical" Latin American students who are more anxious, withdrawn, diffident.

The Southeast Asia languages (Chinese, Vietnamese) are very different from Russian, so the Chinese and Vietnamese students have many problems with phonetics, grammar, vocabulary. It is much easier for them to master the Russian cursive. Chinese students tend to prefer to communicate with their compatriots in their own language, and it makes it difficult for them to learn the Russian language. They are not accustomed to take the initiative in learning, they are waiting for questions and directions from the teacher. If Chinese students are motivated to study in Russia, they compensate all the difficulties by diligence and hard work.

The experts point out that the Russian system of education has accumulated a lot of experience of working with foreign students and teaching them the Russian language:

- there are various books and manuals, which are aimed at students from different regions (based on their native language or mediator language) [for example: 3; 7 etc.];

- there are specially formed international groups at the preparatory faculty, so students can communicate with each other in Russian;

- a lot of attention is paid to the intercultural competence of students, so they learn not only the Russian language but Russian culture, history, customs etc. $[1 ; 2 ; 6]$.

Extracurricular work with international students also helps them to learn the Russian language: 1) excursions around Moscow and other cities; 2) music clubs and concerts (singing helps to master phonetics); 3) Olympiads and Competitions in the Russian language, etc. [4].

In such a way after 10-12 months from their arrival in Russia, most foreign students are ready to study all the subjects in Russian at the main faculties. They can listen to lectures, read textbooks independently to prepare for seminars. However, the lessons of the Russian language will continue until their graduation (about $4-6$ hours per week).

We think that the revealed features of the Russian language acquisition should be considered in the development of special cross-cultural training programs aimed at both students and teachers of the multinational universities. 


\section{REFERENCES}

[1] Бальххина T.M. Научные теории и практика коммуникативной адаптации в новой языковой среде и образовательном пространстве // Вестник РУДН. Серия «Вопросы образования: языки и специальность». - 2010. — № 4. - C. 9-17. [Balykhina T.M. Nauchnye teorii i praktika kommunikativnoj adaptacii v novoj yazikovoj srede i obrazovatelnom prostranstve // Vestnik RUDN. Seriya "Voprosy obrazovaniya: yazyki i specialnost". — 2010. — N 4. — S. 9-17.]

[2] Бальхина T.M. Русский язык и русское видение мира: коммуникативно-поведенческий аспект // Вестник РУДН. Серия «Психология и педагогика». — 2013. — № 2. - С. 31-36. [Balykhina T.M. Russkij yazyk i russkoe videnie mira: kommunikativno-povedencheskij aspekt // Vestnik RUDN. Seriya "Psikhologiya i pedagogika". — 2013. — No 2. — S. 31 -36.]

[3] Балыхина Т.М., Евстигнеева И.Ф., Маерова О.Л. и др. Учебник русского языка для говорящих по-китайски. - М.: Русский язык. Курсы, 2000. [Balykhina T.M., Evstegneeva I.F., Maerova O.L. $i d r$. Uchebnik russkogo yazyka dlya govoryaschikh po-kitajski. - M.: Rus. yaz. Kursy, 2000.]

[4] Казаренков В.И. Формирование у студентов опыта межкультурного взаимодействия: резервы университетского образования // Российский научный журнал. - 2014. № 1 (39). - C. 83-91. [Kazarenkov V.I. Formirovanie u studentov opyta mezhkulturnogo vzaimodejstvija: rezervy universitetskogo obrazovanija // Rossijskij nauchnyj zhurnal. 2014. — No 1 (39). — S. 83-91.]

[5] Новиков А.Л., Рыбаков М.А. Функционирование русского языка: основные тенденции и их причины // Вестник РУДН. Серия «Вопросы образования: языки и специальность». 2011. — № 4. — C. 47-54. [Novikov A.L., Rybakov M.A. Funkcionirovanie russkogo jazyka: osnovnye tendencii i ih prichiny // Vestnik RUDN. Serija "Voprosy obrazovanija: jazyki i specialnost". — 2011. — No 4. - S. 47-54.]

[6] Ромеро Интриаго Д.И. Лингвокультурологический аспект в преподавании русского языка как иностранного // Вестник РУДН. Серия «Вопросы образования: языки и специальность». - 2010. — № 4 - C. 52-54. [Romero Intriago D.I. Lingvokulturologicheskij aspekt v prepodavanii russkogo yazyika kak inostrannogo // Vestnik RUDN. Seriya "Voprosy obrazovaniya: yazyki i specialnost". — 2010. — N 4. — S. 52-54.]

[7] Хавронина С.А., Широченская А.И. Русский язык в упражнениях: Учебное пособие (для говорящих на английском языке). — 14-е изд., стереотип. — М.: Рус. яз., 2000. [Khavronina S.A., Shirochenskaya A.I. Russkiy yazyik v uprazhneniyah: Uchebnoe posobie (dlya govoryaschikh na angliyskom yazyike). - 14-e izd., stereotip. — M.: Rus. yaz., 2000.]

[8] Chebotareva E.Ju. Intercultural Adaptation to Russia of Students from Asia, Africa, Latin America and the Middle East // Bulletin of Peoples' Friendship University of Russia. Series "Psychology and Pedagogics". — 2011. - No 3. - P. 6-11.

[9] Chebotareva E.Ju. Foreign language acquisition // The Encyclopedia of Cross-Cultural Psychology / Ed. Kenneth D. Keith. - Hoboken, New Jersey: Wiley-Blackwell, 2013. P. $560-564$.

[10] Novikov A., Novikova I., Shkvarilo K. Psychological and linguistic specifics of the foreign language acquisition by multinational university students // Language and Super-diversity: Explorations and interrogations: Abstracts. — Jyvaskyla, Finland, 2013. — P. 179—180. 


\title{
ПСИХОЛОГИЧЕСКИЕ И ЛИНГВИСТИЧЕСКИЕ ОСОБЕННОСТИ ОСВОЕНИЯ РУССКОГО ЯЗЫКА ИНОСТРАННЫМИ СТУДЕНТАМИ
}

\author{
И.А. Новикова \\ Кафедра социальной и дифференциальной психологии \\ Российский университет дружбы народов \\ ул. Миклухо-Маклая, 10/2, Москва, Россия, 117198 \\ А.Л. Новиков, М.А. Рыбаков \\ Кафедра общего и русского языкознания \\ Российский университет дружбы народов \\ ул. Миклухо-Маклая, 10/2, Москва, Россия, 117198 \\ В статье представлены результаты развернутого интервью с преподавателями русского языка, \\ которые обучают иностранных студентов в многонациональных университетах. Выявлены основные \\ психологические и лингвистические особенности, характерные для студентов из разных регионов \\ мира (страны Африки; Латинской Америки; Юго-Восточной Азии; Арабские страны) при изучении
} русского языка.

Ключевые слова: русский язык как иностранный, преподавание русского языка, изучение русского языка, иностранные студенты, межкультурная коммуникация и адаптация. 